\title{
Sexual precocity with pituitary macroadenoma and bilateral multicystic ovaries - a case report
}

\author{
S Ramkumar , Parjeet Kaur, Ansu Joshi, AC Ammini, \\ From 7th APPES Biennial Scientific Meeting \\ Nusa Dua, Bali. 14-17 November 2012
}

\begin{abstract}
Aim
To report a 6 years old girl who presented with sexual precocity, multicystic ovaries and pituitary macroadenoma due to primary hypothyroidism.
\end{abstract}

\section{Methods}

We describe the clinical presentation, imaging findings, hormonal work-up and follow up of a child with sexual precocity, multicystic ovaries and pituitary macroadenoma due to primary hypothyroidism

\section{Results}

6 year old girl presented with vaginal bleeding for last $1 \frac{1 / 2}{2}$ years. The initial episode lasted 3 days. The vaginal bleeding then continued every month lasting 3-4 days for next 9months. She also had inter-menstrual bleeding for last 6 months. Parents also noticed breast development (initially left followed by right a month later) for the past 6 months. There was no galactorrhoea, pubic or axillary hair development. There was no height gain during the last 2 years, but weight increased from $14 \mathrm{~kg}$ to $19 \mathrm{~kg}$. Her appetite was normal. Parents also noticed a generalized edema of face, abdomen and legs. There was no history of constipation, cold intolerance or goiter. Her past history was unremarkable. She goes to Anganwadi School but has decreased mentation compared to younger sister. On examination, she was $95.5 \mathrm{~cm}$ tall $\left(<3^{\text {rd }}\right.$ percentile), weight was $19 \mathrm{~kg}$ $\left(25^{\text {th }}\right.$ percentile $)$. Her skin was rough and dry, heart rate was $80 / \mathrm{min}$ and BP $100 / 80 \mathrm{~mm}$ of $\mathrm{Hg}$. There was no goiter or lingual thyroid. Tanners staging was B3P1. Galactorrhoea present on gentle manipulation. There was no axilliary hair, genital hyperpigmentation or clittoromegaly. Her cardiac and respiratory examinations were normal. On abdominal examination, a soft cystic fluctuant mass palpable in hypogastrium, dull on percussion, well defined

Dept of Endocrinology and Metabolism, AllMS, New Delhi, India on all sides except inferiorly where lower margin was not palpable. Neurological examination showed dull lethargic child with excessive somnolence. The tendon reflexes are normal. Her bone age was delayed 3.2 years. Investigations: Hemogram, renal and liver functions are normal.

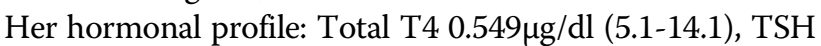
$>100 \mu \mathrm{IU} / \mathrm{ml}(0.27-4.2)$, TPO antibody $-74.01 \mathrm{pg} / \mathrm{ml}$ (<34), LH $<0.10(2.4-12.6)$, FSH $7.78 \mathrm{mIU} / \mathrm{ml}(3.5-12.5)$, prolactin $337.7 \mathrm{ng} / \mathrm{ml}(6-29.9)$, Estradiol $2113 \mathrm{pg} / \mathrm{ml}(<20)$, Cortisol $15.95 \mu \mathrm{g} / \mathrm{dl}(6.2-19.4)$, testosterone $0.029 \mathrm{ng} / \mathrm{ml}$ (0.084 - 0.481), DHEAS 39.37 $\mu \mathrm{g} / \mathrm{dl}(2.8-85.2)$, ACTH $11.71 \mathrm{pg} / \mathrm{ml}(7.2-63.3)$. USG neck revealed presence of thyroid in normal location. USG and CT pelvis showed bilateral multiple cystic ovaries and bulky uterus. MRI sella reported as pituitary macroadenoma. Child was started on tab.thyroxine $50 \mathrm{mcg} /$ day. Child lost $4 \mathrm{~kg}$ and gained $1.5 \mathrm{~cm}$ in 2 months and became active. Repeat hormonal work up showed: Total T4 $10.59 \mu \mathrm{g} / \mathrm{dl}$, TSH $3.18 \mu \mathrm{IU} / \mathrm{ml}$ and prolactin $71 \mathrm{ng} / \mathrm{ml}$. she was diagnosed as hashimoto thyroiditis/hypothyroidism with pituitary macroadenoma and sexual precocity.

\section{Results}

Short stature in sexual precocity - think of primary hypothyroidism. Multi cystic ovaries and pituitary enlargement although rare, may be seen in children with longstanding primary hypothyroidism. It is important to be aware of this to avoid pituitary surgery which may have disastrous results in these patients.

Published: 3 October 2013
doi:10.1186/1687-9856-2013-S1-P200

Cite this article as: Ramkumar et al:: Sexual precocity with pituitary macroadenoma and bilateral multicystic ovaries - a case report. International Journal of Pediatric Endocrinology 2013 2013(Suppl 1):P200. 